\title{
RESEARCHPAPER
}

\section{Isolation and functional characterization of cadmium resistant strains RCP 1 using agronomical parameter of Chaulai (Amaranthus tricolor L.)}

\author{
ANJALI TIWARI ${ }^{1}$, O.P. VERMA ${ }^{1}$ AND MANISHI TRIPATHI ${ }^{2}$ \\ ${ }^{1}$ Department of Molecular and Cellular Engineering, Jacob School of Biotechnology and Bio-Engineering, Sam \\ Higginbottom Institute of Agriculture, Technology and Sciences, ALLAHABAD (U.P.) INDIA \\ ${ }^{2}$ Department of Microbiology, Institute of Biosciences and Biotechnology, Chhatrapati Shahu Ji Maharaj University, \\ KANPUR (U.P.) INDIA \\ Email : om.verma@shiats.edu.in
}

Article Info :Received : 01.12.2015; Revised : 04.01.2016; Accepted : 05.02.2016

Resistance and tolerance are arbitrarily defined terms frequently interchangeable and after based on weather a given isolate can grow in the presence of selected heavy metal concentration in laboratory media. Total bacterial strains were isolated and screened on the basis of their heavy metal tolerance ability for cadmium and their PGPR activity. It was estimated that they have good tolerance power for cadmium the heavy metals and are plant growth promoting rhizobacteria. If we study morphological aspects we can say that Gram negative rods are more efficient in tolerating heavy metals. In case of treatment I, fresh weight was increased 22.22 per cent and dry weight was increased 20.73 per cent compared to positive control. In case of treatment II, fresh weight was increased 42 per cent and dry weight was increased 20 per cent compared to negative control. In case of negative control, fresh weight was decreased 56.52 per cent and dry weight was decreased 50 per cent compared to positive control. By performing experiment it was proved that the cadmium concentration reduced significant percentage of chaulai fresh weight and dry weight but increased when treated with strain RCP 1.

Key words : Rhizobacteria, Tolerance, Resistance, Functional characterization, Cadmium

How to cite this paper : Tiwari, Anjali, Verma, O.P. and Tripathi, Manishi (2016). Isolation and functional characterization of cadmium resistant strains RCP 1 using agronomical parameter of Chaulai (Amaranthus tricolor L.). Asian J. Bio. Sci., 11 (1) : 6-11 [Special Issue of AFBSAH-2016]. 